\title{
Obligations to Negroes Who Would Be Kin If They Were not Negro
}

\section{Citation}

Sollors, Werner. 2011. “'Obligations to Negroes Who Would Be Kin If They Were Not Negro.'” Daedalus 140 (1) (January): 142-153. doi:10.1162/daed_a_00066.

\section{Published Version}

doi:10.1162/DAED_a_00066

\section{Permanent link}

http://nrs.harvard.edu/urn-3:HUL.InstRepos:31902678

\section{Terms of Use}

This article was downloaded from Harvard University's DASH repository, and is made available under the terms and conditions applicable to Other Posted Material, as set forth at http:// nrs.harvard.edu/urn-3:HUL.InstRepos:dash.current.terms-of-use\#LAA

\section{Share Your Story}

The Harvard community has made this article openly available.

Please share how this access benefits you. Submit a story.

Accessibility 


\title{
"Obligations to Negroes who would be kin if they were not Negro"
}

\author{
Werner Sollors
}

WERNER SOLLORS, a Fellow of the American Academy since 2001, is the Henry B. and Anne M. Cabot Professor of English Literature and Professor of African and African American Studies at Harvard University. His publications include Ethnic Modernism (2008) and Neither Black nor White yet Both: Thematic Explorations of Interracial Literature (1997). He edited A New Literary History of America (with Greil Marcus, 2009).
At the present moment there is no one dominant note in Negro literary expression. As the Negro merges into the main stream of American life, there might result actually a disappearance of Negro literature as such. If that happens, it will mean that those conditions of life that formerly defined what was "Negro" have ceased to exist, and it implies that Negroes are Negroes because they are treated as Negroes.<smiles>C=C[Tl]</smiles>

If the expression of the American Negro should take a sharp turn toward strictly racial themes, then you will know by that token that we are suffering our old and ancient agonies at the hands of our white American neighbors. If, however, our expression broadens, assumes the common themes and burdens of literary expression which are the heritage of all men, then by that token you will know that a humane attitude prevails in America towards us. And a gain in humaneness in America is a gain in humaneness for us all. When that day comes, there will exist one more proof of the oneness of man, of the basic unity of human life on this earth.

-Richard Wright, "The Literature of the Negro in the United States” (1957) 1

$\mathrm{R}$ chard Wright, who died in Paris in 1960, was not quoted or mentioned in the special issues of Dadalus on "The Negro American" in 1965 and

(C) 2011 by the American Academy of Arts \& Sciences 
1966. However, many contributors to the issues shared Wright's interest in confronting the conditions that have defined the lives of American Negroes and have caused them to suffer agonies at the hands of their white neighbors. ${ }^{2}$ Wright's forward-looking comment, his imagining of a different and perhaps better future, anticipated a possible exhaustion of the African American narrative, 3 and the Docdalus contributors likewise made cautious predictions for the future. Returning to those prophecies from several decades ago makes for a fascinating enterprise.

The most intriguing prophet from the Doedalus issues was Everett C. Hughes, whose essay "Anomalies and Projections" focused on the disturbance that racial distinctions have created in the American kinship system. ${ }^{4}$ At the time Hughes was writing, people from other races could not be or become white people's kinfolk, and the proverbial Negro who married a white man's sister would not only sever the kin relationship between brother and sister, but would also bring shame upon the white man that would justify violence, even to the point of killing the Negro. As Hughes explained, "there is a great moral fault - in the geological sense, and let us not quibble about the other sense - in American society when it comes to obligations to Negroes who would be kin if they were not Negro." Hence, race could "mean the difference between friend and enemy, one's own to be trusted or outsider to be feared, between life and death." 5 No wonder the white eye was trained to detect racial difference, though its ability to do so could vary in certain circumstances.

Hughes wrote his essay in 1965, but his examples surprise the reader still today:
If the Negro does not wear one of the many uniforms of deference or of povWerner Sollors erty or play some role in which we expect Negroes to appear, the Negro-ness might not be noticed. On the other hand, there might be situations in which it would be doubly noticed. Imagine a handsomely purple-black Negro woman in a decolleté white gown at the ball celebrating her husband's inauguration as President of the United States. ${ }^{6}$

Hughes thought about Negroes "in prestigeful positions" in order to contemplate such questions as "does the office outshine race or does race dim the luster of the office?" He imagined the broader possibility that in the future there might be "the full extension of the American bilateral kinship system to include mixed couples and their in-laws on both sides." Although Hughes was writing two years before Loving v. Virginia, he ventured the claim, "Perhaps there will come to be cases where mixed couples and their children will be able to lead normal lives, with real uncles and aunts and cousins on both sides."7

The he parallel between Hughes's hypothetical scenario and Barack Obama's presidential campaign, election, inauguration, and family history is difficult to ignore. In his famous "race" speech, delivered in Philadelphia on March 18, 2008 , then-candidate Obama reiterated his place within a multigenerational family network:

I am the son of a black man from Kenya and a white woman from Kansas. I was raised with the help of a white grandfather who survived a Depression to serve in Patton's Army during World War II and a white grandmother who worked on a bomber assembly line at Fort Leav- 


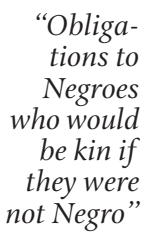

enworth while he was overseas. I've gone to some of the best schools in America and lived in one of the world's poorest nations.

Positioning himself as an ideal mediator between races, continents, and classes precisely because of his interracial family background, he added his marriage to the story: "I am married to a black American who carries within her the blood of slaves and slave owners - an inheritance we pass on to our two precious daughters." Obama employed his complex family story not only to suggest harmonious American fusion ("it is a story that has seared into my genetic makeup the idea that this nation is more than the sum of its parts - that out of many, we are truly one") but also to stress that having both black and white relatives gives him a more sober perspective on what is secretly felt on both sides of the color line. He pledged that his presidency would help overcome this racial "stalemate," and he offered unusually candid critical comments to both blacks and whites in an effort to reach for this goal and heal old racial wounds. ${ }^{8}$

After the inauguration, The New York Times (with the help of genealogist Megan Smolenyak) researched Michelle Obama's ancestry, following up on Obama's hint that his wife carries "the blood of slaves and slave owners." Illustrated with an interactive family tree, ${ }^{9}$ the Times story mentions a "union, consummated some two years before the Civil War," representing "the origins of a family line that would extend from rural Georgia, to Birmingham, Ala., to Chicago and, finally, to the White House. Melvinia Shields, the enslaved and illiterate young girl ['perhaps as young as 15,' we are told elsewhere in the story], and the unknown white man who impregnated her are the greatgreat-great-grandparents of Michelle
Obama, the first lady." The article concludes that this genealogy "for the first time fully connects the first AfricanAmerican first lady to the history of slavery, tracing their five-generation journey from bondage to a front-row seat to the presidency." 10 Hughes's observations about American society and its "obligations to Negroes who would be kin if they were not Negro" would seem to apply very directly to the white and the non-white branches of the first lady's family.

Of course, it was the inauguration ball that offered the uncannily literal fulfillment of Hughes's prophecy. Michelle Obama's white dress received much media attention on its own: New York Times fashion critic Cathy Horyn even called it "a bit revealing."11

Though it lacks an inaugural ball scene, best-selling writer Irving Wallace's 1964 novel The Man, which imagines the first black president, perhaps inspired Hughes. (When Obama was inaugurated, Wallace's son David Wallechinsky reminded the public of his father's novel, the first American novel about a black president; however, the book seems to have been largely forgotten. ${ }^{12}$ ) In The Man, President Douglass Dilman is not elected but ascends to his office as pro tempore Senate leader after the president and vice president die in an accident abroad. Wallace calls attention to the significance of Dilman's first name with an epigraph by Frederick Douglass. ${ }^{13}$ Dilman's late-night swearing-in ceremony inspires newspaper headlines ranging from sensationalism to segregationism to racial pride:

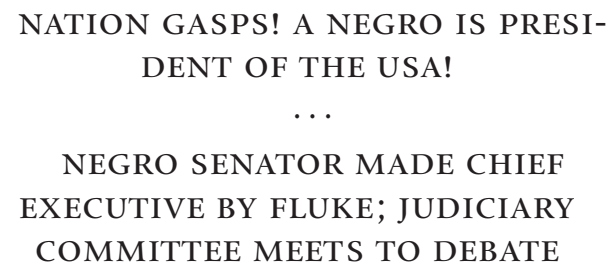


CONSTITUTIONALITY; CITIZENS PROTEST "UNFAIR" RULE OF MAJORITY BY MINORITY; REPRESENTATIVE MILLER PREDICTS “DISSENSION, DISUNITY, VIOLENCE” ...

HALLELUJAH! EQUAL RIGHTS AT LAST! COLORED PRESIDENT OF SENATE BECOMES PRESIDENT OF US ALL! WORLD APPLAUDS TRUE DEMOCRACY!

Wallace's narrator mediates these varied reactions; he comments: "Several things were evident at once. To no one would he be simply a public servant who, by the law of succession, had become President of the United States. To both sides, and the middle, too, he would be the 'Negro' who had become President."14

Wallace's narrator reminds us of the question Hughes raises in his Doedalus essay, as well as how it might apply to the present: that is, does President Obama's office outshine race, or is the country divided between people who think it does and others still preoccupied with his ancestry? Contemporary responses to this question vary from high optimism to deep skepticism. In "Our Man Obama: The Post-Imperial Presidency," the Vietnamese American essayist Andrew Lam views Obama's election as a boost for a multicultural America because it symbolically strengthened the culturally subservient role Friday plays to Robinson Crusoe. The victory opened "the door wider to that growing public space in which Americans with mixed background and complicated biographies Latino Muslims, black Buddhists, gay Korean Jews, mixed race children - can celebrate and embrace their multiple narratives with audacity." 15 Lam tempers his enthusiasm when he adds that, with the election, America has not moved into a utopia; that bigotry, racism, and struggles over resources and for power Werner Sollors will remain with us. Yet he concludes on the hopeful note that Friday's/Obama's "talent is the ability to overcome the paralysis induced by multiple conflicting narratives and selves by finding and inventing new connections between them." 16 Ishmael Reed, who commented critically on the public responses "to the election of the first Celtic-AfricanAmerican president," saw a sharp contrast between a celebratory façade and the media's continued practice of ignoring black voices: "On the day after the election the New York Times announced in its headline that Obama's election had broken a barrier, yet on the editorial page all of the poets who were invited to chime in were white. Some barriers remain." 17

$\mathrm{W}_{\mathrm{h}}$ hat relevance does Richard Wright's "The Literature of the Negro in the United States" have for contemporary African American literature ${ }^{18}$ What themes emerge in literary works by young authors who achieved first recognition in the twenty-first century, who have Facebook sites and are Internet savvy? Do their works conform to one or the other of Wright's choices? Do poetry, drama, and fiction in "the age of Obama" engage with some semblance of Everett Hughes's notion of extended kinship?

Younger contemporary African American writers address race in many different ways in their works. Amina Gautier, a fiction writer in her early thirties, uses the thwarted fantasy of a happy extended family gathering for Thanksgiving to explore themes that transcend race. In her melancholy short story "Been Meaning to Say" (2008), ${ }^{19}$ she follows the recently widowed grandfather Leslie Singleton, his surname a signal of his loneliness. His younger white neighbor, Joey 
"Obliga- Leibert, is about to sell his house, which is tions to semi-attached to Leslie's but which LesNegroes who would

be kin if though Leslie tells Joey that his daughter, they were, Carole, his son-in-law, Martin, and his eight-year-old grandson, Amir, are all coming for Thanksgiving, his false hope becomes excruciatingly evident. Carole, an assistant professor whom the reader encounters only through cell phone calls, seems distant from her father. Leslie, exhibiting the first signs of senility, desperately misses his late wife, Iphigenia, and does not seem to want to pronounce his grandson's Arabic name: Leslie thinks of it as "mumbo jumbo." When a black family arrives on Thanksgiving to look at the Leiberts' house, Leslie feels strongly that they should not buy a house for their children: "They will grow up and they will leave it. They will leave you," he feels like saying to them. ${ }^{20}$ The turkey is in the oven, underdone, but Mr. Singleton spends the holiday alone seated in front of the television with his remote control.

"Been Meaning to Say" is a short story of manners in which race plays no dominant or plot-constitutive role. Perhaps it does explain why Singleton has never seen his closest neighbor's house from the inside, but that might also be due to Singleton's character. While Joey is described as a "lanky white man," and the Leiberts are identified as "the last white family to move off the block," Singleton is never given a racial label. ${ }^{21}$ There are specific references to African American naming practices from the generation of Eunettas and Anna Maes to that of Singleton's grandson, whose Arabic name means prince or ruler, as Carole tells her father on the phone. Yet the themes of intergenerational and neighborly alienation, of an aging man's grief and loneliness, belong to Richard Wright's "common themes and burdens of literary expression which are the heritage of all men." Narrative subtlety and the full development of Leslie Singleton's character carry the story, but there is little external action, no dramatic turning point or conflict, no epiphany.

The same is true of Gautier's "Pan is Dead" (2006), a short story about Blue, a runaway dad who comes back to his wife, son, and stepdaughter (who narrates the story) after a long absence. Blue is still charismatic, but he is also still a junkie and before long he leaves the family once again. Though published two years before Obama's election, one moment in the story looks different now from the way it might have in 2006. The narrator's brother says to her, "I don't want to be a doctor. [...] But I could be a lawyer. Most presidents are lawyers first." She responds: “'Boy, you can't be president.' This much I knew. Everyone knew that the president was always white and never from Brooklyn." 22 Four years later, Gautier's Facebook profile lists her as a member of the "We Love Michelle Obama!!!!” group. ${ }^{23}$

A tragic moment of high tension is the background to Heidi W. Durrow's first novel, The Girl Who Fell from the Sky (2010). ${ }^{24}$ Durrow, born in 1969, was inspired by Nella Larsen, whose words serve as an epigraph for the novel. Like Larsen, both Durrow and her protagonist, Rachel, are biracial Danish-African American figures. ${ }^{25}$ Rachel's mother Nella, whom she calls "Mor," is Danish; Rachel's grandmother is black; her father Roger is a black GI (her parents met at an army base in Germany); and Rachel is biracial. At one point in the novel, Rachel, who now lives with her paternal grandmother, receives a package with two books that symbolize her situation: Frantz Fanon's Black Skin, White Masks and Hans Christian Ander- 
sen's fairy tales. As the form of the novel indicates, William Faulkner's experiments with point of view in The Sound and the Fury (1929) and As I Lay Dying (1930), as well as Toni Morrison's reconstruction of a traumatic moment of flying in Song of Solomon (1977), undoubtedly also influenced Durrow. The two-part novel is divided into forty-four sections, nineteen of which are told in the first-person present tense by Rachel, seven in a more staccato firstperson present by her mother Nella, two in the third-person past tense from her father Roger's point of view, and the others by friends and neighbors, also in the third-person past tense. This chorus of voices surrounding the central presence of Rachel and her mother slowly reveals and offers various attempts to understand, from different points of view, the terrible moment that is the core of the novel: when the deeply depressed Nella takes her three children, Robbie, Ariel, and Rachel, and jumps off the rooftop with them in an act of utter despair. Only Rachel survives. A first glimpse of the story comes through the eyes of a little boy, Jamie, who loves bird-watching and thinks at first that he sees birds when he witnesses the event:

When he finally reached the courtyard, he saw that his bird was not a bird at all. His bird was a boy and a girl and a mother and a child.

The mother, the girl, the child. They looked like they were sleeping, eyes closed, listless. The baby was still in her mother's arms, a gray sticky porridge pouring from the underside of her head. The girl was heaped on top of the boy's body, a bloody helpless pillow. And yet there was an old mattress, doughy from rain, just ten feet from the bird-boy's right arm, which was folded like a wing beneath him. ${ }^{26}$
The novel moves on to other external perspectives and glimpses of the more distant past (there was an earlier child, Charles, who died; Rachel knew nothing of him) and the later present (Rachel is becoming a woman). Finally, Durrow confronts the event through Nella's and Rachel's own voices. Nella claims the children as her own against other people's (and especially her white boyfriend Doug's) racist perceptions: "They're mine. If people can't see it - how can I keep them safe? ... They will go where I go." Rachel recounts the jump from the rooftop more fully: "I saw above me and around, beyond the day's fog. I felt my cells expanding into space and felt larger than ever before. And then I met the ground." 27

In a Readers' Guide found on her website, Durrow raises the question, "Do you think that in the age of Obama, biracial/bicultural people will continue to experience the same kinds of stereotypes and stigma that Rachel did?"28 The Girl Who Fell from the Sky thematizes not only the still common misperception that a white mother of mixed-race children must be an adoptive parent, but also Rachel's sense of biracial and semiDanish estrangement in her grandmother's black world. Though the novel may ultimately find its source of horror in a good mother's growing mental disturbance more than in social conditions or race relations, there is little hope here that Hughes's American problem of those "who would be kin if they were not Negro" has reached a happy resolution in 2010. Yet the horrifying maternal act that has defined Rachel's life has also given her - she who was not meant to have a future - a new life in which she finally is able to express understanding and love of her mother.

Among young playwrights who
emerged in the first decade of the
Werner

Sollors 
"Obliga- twenty-first century, Thomas Bradshaw tions to stands out for his satirical edge and his Negroes broad, poster-like employment of the

be kin if repertoire of American racial histories they were and sexual fantasies in an aggressive black-humor mode that makes audiences initially think they are watching a comedy. ${ }^{29}$ Born in 1980 in New Jersey, Bradshaw wanted to go beyond the midcentury protest tradition:

There's the black literature of the ' 40 , '5os and '6os - white oppression is bad, reparations, apologizing. It was awareness building, really. That work was really necessary and important.... But there hasn't been much work done since then. What is a modern presentation of race? What kind of issues do upper middle class blacks have to deal with? After you assimilate into the mainstream, what are the issues?30

His ironically titled play Strom Thurmond Is Not a Racist (2007) ${ }^{31}$ addresses the paradox that, at the core of racial segregation, there was also miscegenation. The thinly veiled hypocrisy in the case of South Carolina Senator Strom Thurmond's lifelong but secretive support for his and Carrie Butler's illegitimate biracial daughter, Essie Mae Washington-Williams, provides the source material for the play. Bradshaw follows the story chronologically, from Thurmond's seduction of the sixteen-yearold Carrie to the spiriting away of their child through various encounters he has with his daughter later on, all while his political career as a segregationist and opponent of civil rights unfolds. This path gives Bradshaw the opportunity to contrast Thurmond's infatuation - he recites Wordsworth's "Daffodils" to Carrie - with his prayers for purity and his wish to please his excessively racist father, who says such things as, "We had to lynch a thousand Niggers before they learned their place in the South again!" Later, the play juxtaposes Thurmond's own segregationist statements - "We have segregation because God doesn't want blacks and whites to mix" - with his daughter's sad and critical observation:

You become a different person when you stand in front of cheering crowds giving campaign speeches. You're unrecognizable to me. You act and speak completely different from the man I know. The man I know is loving and wonderful to me, the man on stage speaks venomously of my kind. It makes me wonder which is the real you or [if] there's a real you. ${ }^{32}$

In a conversation between Strom and his father, Bradshaw reveals how the public rhetoric against "nigger-loving" (a phrase employed by both men) is only the flipside of what Strom's father calls "a right of passage for most southern gentlemen." His father says: "We learn about women from the promiscuous nigress. They tantalize us. There's something irresistible about them. We demonize them by day and crawl into their beds at night." Strom responds: "But we never let the truth be known. It's our open secret." The play ends with Essie Mae's funeral eulogy for her father, which she concludes with, "I'm going to miss you daddy."33 In explicitly naming the open secret and ending with the word "daddy," Strom Thurmond Is Not a Racist crisply illuminates Everett Hughes's notion of unmet white American "obligations to Negroes who would be kin if they were not Negro."

Racist obstacles to public recognition and acceptance of interracial kinship take center stage as well in Bradshaw's lurid play Cleansed. While wearing a Klan mask her white grandmother gave her, Lauraul, a mixed-race daughter who 
wishes to be white, kills her black father, a heart surgeon, for having contaminated her white blood. This play is a ritual-like revision of black political drama in the wake of the 196os, in which a daughter might kill her father for being a sell-out Negro according to her newly acquired revolutionary black nationalist views (as was the case with M'Balia in Richard Wesley's Black Terror of 1971). But in the twenty-first century of Cleansed, the confused biracial daughter is accepted into a white supremacist group because she hates Negroes even more than the whites do.

In Bradshaw's theatrical world, an extended interracial family sitting down to a happy Thanksgiving dinner in a postracial setting seems unthinkable. In a New Yorker review, Hilton Als confirms the sense that Bradshaw's plays "take a sharp turn toward strictly racial themes" (in Richard Wright's formula). "It's fairly easy to get beyond Bradshaw's purposefully thin surfaces," Als writes, "unless, of course, you're unwilling to look at what contorts all America: racism, and the bullshit notion that it doesn't affect our view of sex and love in a so-called post-racial country."34

B in South Carolina in 1971, the poet Terrance Hayes engages obliquely and self-reflexively with the past as shaped by the civil rights movement, and he does so while experimenting in new poetic forms and with an impressive cultural openness. In his collection of poems Lighthead (2010), he finds inspiration in a mélange of greats: from David Bowie, Fela Kuti, and Etta James to Gwendolyn Brooks, Wallace Stevens, and Elizabeth Alexander (who received broader international attention for her inauguration poem for Barack Obama) to The Hitchhiker's Guide to the Galaxy. 35
Hayes likes to compose pecha kucha poems, a word he explains as "a JapaWerner Sollors nese adaptation/loanword of the word picture, pronounced in three syllables, like "pe-chack-cha." 36 This format, Hayes writes, is derived from Japanese business presentations of twenty connected images of twenty seconds each. Perfect for polished cycles or sequences of poems, the PowerPoint model has inspired a highly contemporary, nontraditional poetic genre that is technology-based and removed from any claims of American or African American authenticity. In one twenty-slide poetic sequence, titled "For Brothers of the Dragon,” Hayes imagined Malcolm X's brothers on the day Malcolm was buried; he includes such self-reflexive slides as:

\section{[HOW FICTION FUNCTIONS]}

However else fiction functions, it fills you with the sound

of crows chirping, alive alive alive. But that's temporary too.

Tell my story, begs the past, as if it was a prayer

for an imagined life or a life that's better than the life you live. 37

"What if blackness is a fad?" Hayes asks in "[MALEDICTION]," a slide of another pecha kucha with the general title, "Arbor for Butch." It is inspired by the African American artist Martin Puryear, the titles of whose works serve as headings for each one of the pecha kucha. Hayes suggests readers search online for these headings and look at the related images. A photograph of Puryear's sculpture Malediction ${ }^{38}$ is thus to be imagined as the inter-artistic background of Hayes's quatrain that continues, after his opening question, with "Dear Negritude, I live as you live, / waiting to be better than I am."39 
"Obliga-
Self-reflexive and ironic uneasiness also characterizes his poem "The Avocado," a sustained conceit on the legacy of civil rights and black nationalist actions. The poem casts the avocado as the ideal emblem for a hypothetical abolitionist flag:

\footnotetext{
"In 1971, drunk on the sweet, sweet juice of revolution,

a crew of us marched into the president's office with a list

of demands," the black man tells us at the February luncheon,

and I'm pretending I haven't heard this one before as I eye

black tortillas on a red plate beside a big green bowl

of guacamole made from the whipped, battered remains

of several harmless former avocados. 40
}

Hayes articulates the distance between the red, black, and green of the black nationalist flag and the commodification of that historical moment, with its sense of political advocacy (a word related to avocado) for such goals as reparations, into the "money-colored flesh of the avocado." The transformation of the avocado into guacamole provides a visual analogy to a recounting of the past that is so palatable and trite that the listener has to pretend not to have heard the story before.

\section{"A}

$A_{t}$ the present moment there is no one dominant note in Negro literary expression": Richard Wright's comment from 1957 echoes still today. Reading Amina Gautier, Heidi Durrow, Thomas Bradshaw, and Terrance Hayes, one encounters rather heterogeneous suggestions about possible story lines for African American literature, as well as diverse approaches to the question whether the country is moving toward a post-racial world in the age of Obama. Yet perhaps there never was only one dominant African American narrative, for writers from Phillis Wheatley and Frank Webb to Albert Murray and Andrea Lee have written about many themes besides race - though racial themes may have been what their readers were looking for most often.

Ironically, no writer makes that more apparent than Richard Wright. Although his most frequently read and taught works emphasize the prototypical African American narrative of victimization, from the legacy of slavery to the ethics of living Jim Crow, he turned away from writing such black proletarian protest poems as "I have seen black hands" and instead experimented with free-floating and untitled haikus that might be of interest to Terrance Hayes: for example, "Crying and crying, / Melodious strings of geese / Passing a graveyard" or "Holding too much rain, / The tulip stoops and spills it, / Then straightens again." Wright also shifted from imagining socially determined and constrained black characters, as in Uncle Tom's Children and Native Son, to focusing on a much broader range of human motivation and psychology in The Outsider and Savage Holiday; he expanded from the legacy of American history in 12 Million Black Voices to take on truly global concerns with tradition and modernity, decolonization, and the emergence of a Third World voice in Pagan Spain, Black Power, and The Color Curtain. ${ }^{41}$ Wright's own willingness to address "strictly racial themes" while also searching for "the common themes and burdens of literary expression which are the heritage of all" is worth remembering, for writers and readers alike, in a world that seems to be post-racial and racial at the same time. ${ }^{42}$ 
${ }^{1}$ Richard Wright, White Man, Listen! (1957 ; repr., Garden City, N.Y. : Anchor Books, 1964), 104-105.

2 Wright's spirit surely was present in the Dadalus issues - in comments on Negroes and Communism in the 1930s; in discussions of the importance of decolonization in the Third World for African American civil rights in the 1950s; and in an essay by St. Clair Drake and references to Horace Cayton, whose joint study Black Metropolis Wright had written an introduction for in 1945. Furthermore, the African American writers who were cited in the issues, Ralph Ellison and James Baldwin, started their careers under the wings of the older Wright.

3 See Charles Johnson, “The End of the Black American Narrative," American Scholar 77 (3) (Summer 2008); http://www.theamericanscholar.org/the-end-of-the-black-american -narrative/ (accessed March 24, 2009).

4 The essay was originally published in Daedalus 94 (4) (Fall 1965): 1133-1147. I quote from the expanded paperback reprint, The Negro American, ed. Talcott Parsons and Kenneth B. Clark (Boston: Beacon Press, 1967). Hughes also reprinted his essay in The Sociological Eye: Selected Papers (Chicago: Aldine-Atherton, 1971).

5 The Negro American, ed. Parsons and Clark, 698, 700.

6 Skeptics may wish to consult the original passage in the Doedalus issue, at page 1139; quote here taken from The Negro American, ed. Parsons and Clark, 70o. See also Hughes's interventions in the discussions of the papers included in Daedalus 95 (1) (Winter 1966): $287-441$. No one seems to have asked a question about this passage in Hughes's essay from the first Dacdalus issue, though Hughes reiterated his reflections on American kinship in the second issue; see page 352.

7 The Negro American, ed. Parsons and Clark, 700, 705-706.

8 http://www.npr.org/templates/story/story.php?storyId=88478467 (accessed February 28, 2010).

9 http://www.nytimes.com/interactive/2009/10/o8/us/politics/20091008-obama -family-tree.html (accessed February 28, 2010).

10 http://www.nytimes.com/2009/10/o8/us/politics/o8genealogy.html?_r=1 (accessed February 28, 2010).

11 http://www.nytimes.com/interactive/2009/01/21/us/politics/20090121-michelle -audioss/index.html (accessed February 28, 2010).

12 http://www.huffingtonpost.com/david-wallechinsky/flashback-the-first -black_b_159301.html (accessed May 7, 2010).

13 Irving Wallace, The Man (New York: Simon and Schuster, 1964), unpaginated front matter. I do not know of a novel by an African American author that anticipated the emergence of a black president.

14 Ibid., $62-63$.

15 Andrew Lam, East Eats West: Writing in Two Hemispheres (Berkeley, Calif. : Heyday Books, 2010), 115; a slightly different version of the essay is available at http://news.newamericamedia.org/news/view_article.html?article_id =e96674231b31155c9ae5adeca7c1eco8 (accessed October 24, 2010).

16 Ibid., 121.

17 Ishmael Reed, Barack Obama and the Jim Crow Media: The Return of the Nigger Breakers (Montreal, Québec: Baraka Books, 2010), 75, 80; cited from page proofs. 
"Obliga-

18 Two first novels from the twenty-first century should also be mentioned. Edward P. Jones's Pulitzer Prize-winning The Known World (New York: Amistad, 2003) is a sweeping historical novel set in slavery-time Virginia that untypically represents slaveholding blacks. Michael Thomas's Man Gone Down (New York: Black Cat, 2007), the winner of the International Dublin/IMPAC Literary Award and one of The New York Times's “Top Ten Best Books of 2007," is a breezy first-person singular account narrated by an interracially married black father living in Brooklyn who confronts his crisis-ridden past and present in four intense days.

19 Originally published in the Southwest Review (2008): 287-297, "Been Meaning to Say" was included in Gerald Early and Nikki Giovanni, eds., Best African American Fiction 2010 (New York: One World, 2010), 106-116, which is the source used for the quotations here.

20 Gautier, "Been Meaning to Say," in Best African American Fiction 2010, ed. Early and Giovanni, 109, 115.

21 Ibid., 106, 110.

22 Amina Gautier, "Pan is Dead," Chattahoochie Review (Fall 20o6): 6; http://www.gpc .edu/ gpccr/gautier.php (accessed February 26, 2010).

23 http://www.facebook.com/people/Amina-Gautier/1339033752 (accessed May 15, 2010).

24 Heidi W. Durrow, The Girl Who Fell from the Sky (Chapel Hill, N.C. : Algonquin Books of Chapel Hill, 2010).

25 Heidi W. Durrow, “Dear Ms. Larsen, There's a Mirror Looking Back,” PMS - poemmemory - story 8 (2008): $101-109$.

26 Durrow, The Girl Who Fell from the Sky, 19-20.

27 Ibid., 247, 238.

28 http://heidiwdurrow.com/readers-guide/ (accessed May 10, 2010).

29 This aspect of Bradshaw's work has affinities with the raucously irreverent tradition Glenda R. Carpio has delineated and analyzed in her book Laughing Fit to Kill: Black Humor in the Fictions of Slavery (New York and Oxford: Oxford University Press, 2008).

30 http://www.brooklynrail.org/2006/12/theater/pushing-buttons-an (accessed May 14, 2010).

31 Thomas Bradshaw, Strom Thurmond Is Not a Racist and Cleansed (New York: Samuel French, 2007).

32 Ibid., 20, 26, 29.

33 Ibid., 32, 39.

34 http://www.newyorker.com/arts/critics/notebook/20o9/o9/28/o90928gonb _GOAT_notebook_als\#ixzzoo1GF6dV6 (accessed May 15, 2010).

35 Terrance Hayes, Lighthead (New York: Penguin, 2010). See also http ://www.pbs.org/ newshour/video/module.html mod=o\&pkg=24042008\&seg=4 (accessed May 12, 2010).

36 Hayes, Lighthead, 94.

37 Ibid., 18.

38 http://updateslive.blogspot.com/2008/06/martin-puryear-exhibition-at-national.html (accessed May 10, 2010).

39 Hayes, Lighthead, 18.

40 Ibid., 27.

${ }^{41}$ Because Wright included observations about the Western dress of Eurasian elites in The Color Curtain, one is tempted to imagine how he might have reacted to Michelle Obama's 
dress at the inauguration ball. The fact that her white gown was designed by Asian American Jason Wu might have added a mediating or "third" dimension to the blackwhite divide that had dominated the discussion of race at a time when the new Asian immigration wave had not yet started - all the more so since Wu commented on the color choice by saying, "White is the most powerful non-color." See http://www .huffingtonpost.com/2009/o1/20/jason-wu-michelle-obamas_n_159519.html (accessed February 28, 2010).

42 I am grateful to Kelsey LeBuffe for research assistance, to Stephen Burt, Gerald Early, Glenda Carpio, and Sara Sollors for helpful comments, to Jennifer Kurdyla and Suzanna Bobadilla for proofreading this essay and suggesting revisions, and to Micah Buis for copyediting it. 